\title{
De corpos duplos: mestiçagem, mistura e relação entre os Karajá de Buridina (Aruanã-GO) ${ }^{1}$
}

\author{
EduARdo S. Nunes
}

resumo Buridina é uma pequena aldeia karajá incrustada no centro da turística cidade de Aruanã (GO), à beira do Rio Araguaia. Na década de 1970, sua população iniciou uma série de casamentos com os não índios regionais, de modo que, hoje, a maioria da população é mestiça. Este fato, aliado ao extremo conhecimento e engajamento desta população no mundo não indígena, não raro faz pesar sobre Buridina o estigma da aculturação. Partindo dos casamentos interétnicos, dos filhos gerados por eles e da forma como os Karajá os classificam para explorar a forma indígena da relaçáo entre as perspectivas indígena e náo indígena, o artigo se dedica a mostrar que, para estes Karajá, o aprendizado e experimentaçáo do mundo dos tori (os brancos) não implica uma "perda cultural". Antes que de um processo aculturativo, trata-se de uma experiência corporal dupla, na qual ambas as perspectivas se relacionam numa unidade repartida.

palavras-chave Mestiçagem. Mistura. Karajá de Buridina. Perspectiva. Relaçóes com os brancos.

Mistura [definição química]

Uma mistura é constituída por duas ou mais substâncias puras [...]. Todas as substâncias que compartilham um mesmo SISTEMA, portanto, constituem uma mistura. Não se pode, entretanto, confundir misturar com dissolver. Água e óleo, por exemplo, misturam-se, mas não se dissolvem. [...]

[1] Uma mistura é dita heterogênea quando apresenta duas ou mais fases e os componentes da mistura são perceptíveis. Observação: a visualização não é, necessariamente, a olho nu. As fases de uma mistura heterogênea podem ser detectadas no microscópio ou separadas em uma centrífuga. Como exemplos têm-se o sangue e o leite. [2] A mistura homogênea é aquela cujas substâncias constituintes não podem ser identificadas [...], pois possuem as mesmas propriedades em toda a sua extensão. Tais substâncias sofrem dissolução, ou seja, a sua mistura produz somente uma fase. Isso quer dizer que toda mistura homogênea é uma solução.

(Wikipédia, a enciclopédia livre - negritos nos original, itálicos do autor)

Os povos indígenas hoje em território brasileiro (e alhures, certamente) têm se empenhado cada dia mais em conhecer e adentrar o mundo não indígena. $\mathrm{E}$ os meios de que têm se utilizado para tal são diversos: educação escolar, formação superior, busca por formas de conseguir dinheiro e bens - seja por trabalho pessoal, benefícios sociais, parcerias ou projetos -, entre outros. A presença indígena nas cidades, viver com e como o branco em suas "grandes aldeias", é mais um destes meios e talvez mesmo o de maior intensidade. A aldeia karajá de Buridina, sobre a qual este artigo versa, é um caso extremo de conhecimento e experimentação do mundo não indígena. Situaçóes como esta (dentro ou fora das cidades, em graus distintos), entretanto, foram por muito tempo (e ainda o são, em

cadernos de campo, São Paulo, n. 19, p. 1-384, 2010 
larga medida) pensadas fora do escopo da "tradição" indígena como se, quando o que está em questão é "virar branco", os índios estivessem fazendo algo fundamentalmente diverso do que fazem usual e/ou tradicionalmente. Dois pesos e duas medidas. Com o exemplo etnográfico abordado neste texto, tento unificar as medidas, i.e., pensar tanto a incursão indígena no mundo dos brancos como as "práticas tradicionais" a partir de um único parâmetro. Mais precisamente, a partir da maneira como os Karajá pensam os muitos casamentos entre índios e não índios existentes nesta aldeia e os filhos gerados por eles, o texto visa explorar a linguagem da mistura como expressáo geral do ponto de vista deste grupo sobre a relação entre seu próprio mundo e o mundo dos tori, os brancos.

Os Karajá, grupo falante de uma língua tardiamente classificada dentro do tronco Macro-Jê - o inỹrybè ${ }^{2}$, ocupam imemorialmente a calha do Rio Araguaia. A maior parte de suas aldeias está situada na Ilha do Bananal (TO). Buridina é a aldeia situada mais a montante desse território, na margem goiana da divisa com o estado do Mato Grosso. No início do século XX, Buridina estava situada ao lado - separada apenas pelo córrego Bandeirantes ${ }^{3}$ - de um presídio, chamado Santa Leopoldina, em torno do qual cresceu um pequeno vilarejo homônimo. Tendo sido outrora, segundo a memória de seus moradores, a maior aldeia karajá de que já se teve notícia, na década de 1940 dois incidentes relacionados à feitiçaria dispersam quase toda sua populaçáo. Buridina se vê, entáo, resumida a um homem, Jacinto $M a(k)$ urehi, que opta por ficar ali e reúne em torno de si, nas décadas subsequentes, um pequeno contingente de parentes, em torno do qual ela se reestruturou. Na década de 1970, a já então cidade de Aruaná começa a se expandir e atravessa o córrego Bandeirantes. Cerca de uma década depois, a aldeia já está, exceção feita ao lado rio, rodeada pela malha urbana, restrita a um espaço de aproximadamente $10.000 \mathrm{~m}^{2}$. Ainda nos anos 1970, a pequena população da aldeia, restrita a um núcleo de parentes muito próximos, inicia um processo de intercasamento com a população regional, processo esse que ainda hoje segue seu curso ${ }^{4}$.

Hoje, Buridina é uma pequena aldeia - com cerca de 200 habitantes - incrustada no centro da turística cidade de Aruaná (GO). Por meio do Projeto de Educaçáo e Cultura Indígena Maurehi, iniciado em 1994, sua população vem esforçando-se para reverter alguns processos traumáticos sofridos ao longo de sua história - principalmente a perda parcial da língua indígena -, sobretudo no difícil período das décadas de 1970 e 1980, quando foram vítimas de muita pressão e preconceito por parte dos regionais 5 . A ideia de aculturaçáo, porém, não é apropriada para descrever a situaçáo desta aldeia, apesar de este ser um estigma que ainda hoje pesa muito sobre ela. Para entendermos o porquê disto, devemos prestar atenção na forma indígena da relação entre sua própria perspectiva e a dos brancos.

\section{Um sistema de perspectivas insolúveis}

Uma aldeia no centro da cidade, "moderna, não é?”, me dizia um homem karajá. À beira do rio Araguaia, dois espaços usualmente pensados como em tudo distintos, opostos, aldeia e cidade, se encontram espacialmente conjugados, mas não diluídos: Buridina nunca perdeu sua tradicional configuração de aldeia karajá ${ }^{\mathbb{x}}$, e o crescimento da cidade (e, posteriormente, a demarcação da terra indígena) não acabou com a distintividade do espaço da aldeia, apenas fez com que os limites de ambas coincidissem (uma única linha serve de borda às duas figuras). Como num minúsculo bairro, passar da aldeia para a cidade é dar um passo através do portão: do meio fio para lá está um mundo de Outros.

Essa afirmação, na verdade, é um tanto imprecisa: o mundo dos tori náo está apenas na cidade e, num certo sentido, Buridina é também parte da cidade. Os Karajá comem nossas 
comidas, estão integrados ao comércio local, usam nossas roupas, nossa língua, nossos nomes, têm televisóes, telefones, fogóes, geladeiras, freezers, bicicletas, algumas motos, camas, guarda-roupas, barracas de acampamento, canoas de alumínio com motores de popa, etc., além do fato de terem muitos amigos não indígenas na cidade e, sobretudo, filhos com eles. Hoje os Karajá de Buridina se dizem misturados, classificando as crianças resultantes desses casamentos como mestiços, termo também usado pelos brancos para se referirem a eles. Uma aldeia incrustada no centro da cidade, habitada por índios "aculturados", em sua maioria mestiços, que levam uma vida de branco. Para a maioria dos moradores e visitantes de Aruanã, a aldeia é apenas mais um bairro da cidade e os índios pouco se diferenciam deles.

Essa é apenas uma forma de contar a história, eu diria. Há também as relações de parentesco, o inỹrybè, as comidas típicas, as disputas políticas características do grupo, xamanismo (ainda que sem xamãs reconhecidos), práticas de resguardo, nominação, etc. Importante notar, entretanto, que tampouco se trata de um mero preconceito: os próprios índios, por vezes, contam essa história. Não se trata, assim, de escolher, entre as duas versóes, qual seria mais apropriada para descrever essa comunidade. Nem, muito menos, de escrever uma "história do meio", algo como uma negação de seu estigma de aculturados por meio do reconhecimento de que seu engajamento extremo no mundo não indígena não lhes tira a condição de indígenas, pois sua tradição não está em contradição com a nossa "modernidade". Não que isso não seja verdade. Detenhamo-nos um pouco aqui.

Para explorar esta questão, tomarei o exemplo de um autor: Roberto Cardoso de Oliveira. O que se segue, entretanto, não é propriamente uma crítica a respeito de seu trabalho. Explorando (parte de) seus argumentos, quero apenas evidenciar a maneira como ele constrói a relação entre "os dois lados", isto é, como aí se relacionam o ponto de vista indígena e o não indígena, "o [mundo do] índio e o mundo dos brancos".

Neste seu livro (1972), Cardoso de Oliveira trata de uma situação que apresenta características similares às que encontramos entre os Karajá de Buridina. Ele fala dos índios ticuna do alto curso do Rio Solimóes, que num contexto de extrativismo de caucho estavam, à época, bastante integrados à sociedade regional, sendo reconhecidos pelos não índios como "caboclos". Num memorial escrito por posseiros, ocupantes da reserva indígena, ao então presidente da república, estes chegam a declarar que não havia "neste recanto índios e sim civilizados caboclos" (Op. cit., p. 110). O autor certamente não compactua com esta visão. "A interiorização dos padrôes de comportamento do branco pelo índio"' (Op. cit., p. 100) não é, a seu ver, suficiente para promover a transformação total dos "Tukúna" em "civilizados". Para justificar essa posição, o autor se apoia no mecanismo "tribal" de autorreconhecimento: a afiliação clânica. Assim, "a condição de membro de um clá confere a um indivíduo o status sem o qual ele não teria lugar na comunidade indígena, pois não seria reconhecido como Tukúna. Em outras palavras, não pertencer a nenhum clã é não ser Tukúna” (Op. cit., p. 66), dando exemplos tanto de um indivíduo com grande conhecimento sobre questôes culturais do grupo que não é reconhecido como indígena (e não se reconhece como tal) por não possuir filiação clânica quanto de outro que, mestiço criado junto à sua mãe não indígena e tendo herdado o clã de seu pai ticuna, "em nenhum momento deixou de ser aceito pela comunidade indígena" (Op. cit., idem). Outro elemento fundamental para a permanência dos Ticuna enquanto tais é o sistema de parentesco, que lhes fornece "meios para calcularem sua posição no contexto intratribal, classificando-os num sistema de status" (Op. cit., p. 71). As- 
sim, a respeito dos "resultados da interferência entre duas ordens distintas, a tribal e a nacional" (Op. cit., p. 70), o autor conclui:

É míster considerar que os Tukúna estão sendo surpreendidos num momento do processo de sua transformação, i.e., de uma transformação que os afeta de modo total mas cujo processo ainda está muito no começo: o que explica a permanência de uma estrutura social segmentada em grupos unilineares de descendência, associados em metades exogâmicas, sustentados por um sistema de parentesco extremamente operativo, formando, a bem dizer, o núcleo da ordem tribal Tukúna. Esse núcleo, como área estratégica do sistema social indígena, ainda não foi tocado em suas estruturas cruciais, a despeito da situaçáo de conjunção intercultural existente (Op. cit., p. 80-81).

E se esse núcleo, essa área estratégica, fosse tocado? Sem querer diminuir a complexidade de tal possível situação - nem muito menos as muitas tensôes, pressóes e violências da situação abordada por Cardoso de Oliveira -, creio que só é possível formular a questão desta maneira se pensamos que as duas "ordens" - a "tribal" e a "nacional" - se situam em um mesmo plano, estando, assim, passíveis de mútua interferência; se pensamos que ambas as ordens constituem um único processo; se pensamos, enfim, que o resultado desta "mútua interferência" é uma unidade una. Acredito, entretanto, que, do ponto de vista indígena, essa não é a única forma de relação entre "as duas ordens": elas podem estar em planos distintos, paralelos e independentes, e a unidade formada por esta relação, assim, só poderá ser compósita, repartida. Desta forma, a análise que tal autor faz da figura do caboclo, "o Tukúna transfigurado pelo contato com o branco" (Op. cit., p. 83), desemboca num esquema marcado por uma ambiguidade.
Em certo sentido, o caboclo pode ser visto como resultado da interiorização do mundo do branco pelo Tukúna, dividida que está sua consciência em duas: uma, voltada para seus ancestrais, outra, para os poderosos homens que o circundam. (...) Fracionada sua personalidade em duas, ele bem retrata a ambiguidade de sua situação total (Op. cit.).

A figura do caboclo nos interessa sobremaneira pela proximidade que apresenta em alguns pontos com a figura do mestiço e, sobretudo, com a pessoa misturada. Aqui, entretanto, náo nos deteremos sobre a possibilidade de mútua influência entre os pontos de vista (uma soluçâo), pensando-os em um mesmo plano, como um processo único, mas sobre o que me parece ser outra dimensão desta inter-relação, à qual os Karajá de Buridina conferem maior ênfase: a coexistência de pontos de vista em uma unidade repartida (uma mistura heterogênea). Numa tal situação, um sistema de perspectivas insolúveis, os pontos de vista estão em planos distintos, de modo que o aprendizado da perspectiva tori pelos Karajá não guarda relação necessária com o (des)aprendizado de sua própria perspectiva. Assim, essa "dupla consciência" do caboclo, de que fala Roberto Cardoso de Oliveira, quando a transpomos para a figura do mestiço, não é ambígua, mas sim dupla. $\mathrm{O}$ meio (caboclo ou mestiço) não é um entre dois, no sentido de um lugar intermediário entre os mundos indígena e não indígena. $\mathrm{O}$ meio não é um um, é um dois sem intervalo, no qual, a cada momento, só se pode estar em um dos lados. O meio é ambos os lados, sem nunca sê-los ao mesmo tempo. Não há um ponto de vista mestiço, pois o meio é a possibilidade de ser ambos.

Mas voltemos aos Karajá.

\section{Casamentos}

Vimos que na década de 1970 teve início a mestiçagem ${ }^{10}$. Algumas décadas depois, pode- 
mos perceber que um dos resultados deste processo foi a instauração de um novo padrão de casamentos. Desde então, as uniôes entre dois indígenas é rara e, geralmente, fruto de particularidades das histórias pessoais: o normal, poder-se-ia dizer, é casar com tori. Mas antes de irmos a uma caracterização do atual estado das unióes, vejamos de que maneira os Karajá conceitualizam esta questão.

Há uma tríade conceitual indígena básica: puro, mestiço e tori. Indio(a) puro(a), ou simplesmente puro(a), é a pessoa cujos dois genitores são indígenas (ou seja, puros). Os mestiços são os frutos das unióes destes com os tori, i.e., os náo índios ${ }^{11}$. Esta é uma forma geral de classificação, mas que, estritamente, só abrange as duas primeiras geraçóes - A, B, D e E, no Diagrama 1. O que acontece, então, quando descemos neste diagrama? Como são classificados/ pensados os netos, bisnetos, etc., deste primeiro casamento misturado? Os Karajá formulam tal questão a partir de dois principais idiomas: o da geração e o da distância.

O primeiro opera por uma espécie de marcação da geração do indivíduo ao qual se refere. Explico-me. Seguindo o exemplo do Diagrama 1 , se uma mulher pura (A) se casa com um homem tori (B), terão um filha mestiça (E). Se ela (E) se casa novamente com homem tori $(\mathrm{F})$, os

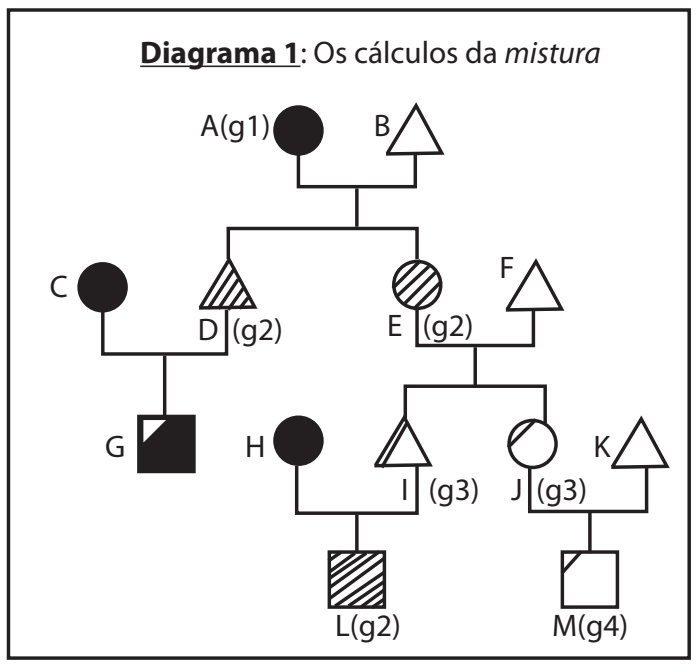

filhos do casal (I, J) serão ainda considerados mestiços, mas "mestiços de terceira geração", ou simplesmente "de terceira geração" (g3, no Diagrama 1). Se um destes (J), por sua vez, repete o matrimônio com não índio $(\mathrm{K})$, os filhos do casal (M) serão ditos "mestiços de quarta geração", ou simplesmente "de quarta geração" (g4). E assim sucessivamente. Por vezes os Karajá se referem aos mestiços (D, E) como "de segunda geração" (g2), sobretudo em contextos em que estão fazendo cálculos sobre um fragmento de genealogia. Mestiço, portanto, é um termo não marcado: pode tanto se referir a qualquer indivíduo que tenha não índios nas geraçôes ascendentes próximas quanto especificamente à "segunda geração". Note-se que esta formulação está focada nos sucessivos matrimônios com os regionais.

Uma segunda formulação está pautada no idioma da distância. Trata-se de uma forma geral de classificação que permite pensar sobre outras situaçóes além dos casamentos com tori. Muitas vezes interpelei pessoas com perguntas tais como: se os filhos de índios com não índios são mestiços, os filhos destes últimos com não índios seriam o quê? Ainda mestiços? Haveria outra categoria para classificá-los? E quanto aos filhos de mestiços com indios puros? Apenas algumas pessoas responderam a essas questóes de forma assertiva: filhos de mestiços com não índios são tori, já não são mais indígenas; e filhos de mestiços com indios puros voltam a ser puros. A maioria das respostas que recebi, entretanto, eram mais vagas - "Rapaz, não sei! Acho que..." -, mas concordam com essa formulação assertiva num sentido: nas falas dos Karajá há um consenso de que o casamento com tori provoca um afastamento em relação à cultura/característica indígena (o que corresponde a uma progressão no esquema das geraçóes, de $\mathrm{A}[\mathrm{g} 1]$ para $\mathrm{E}$ [g2], para J[g3]...), ao passo que casar com índio puro direciona esse processo no sentido contrário (a passagem de $\mathrm{I}[\mathrm{g} 3]$ para $\mathrm{L}[\mathrm{g} 2]$ ou de D para G,

cadernos de campo, São Paulo, n. 19, p. 113-134, 2010 
por exemplo). Assim, quanto aos filhos de mestiços com tori (I, J e M), por exemplo, dizem que "vai distanciando", "vai acabando", "puxa mais para o lado do branco"; já os filhos de mestiços com indios puros $(\mathrm{G})$, "acho que volta [a ser puro], não é?”, "volta de novo", "puxa mais pro lado do índio". Apenas uma pessoa disse que a mistura seria um caminho sem volta, "misturou, está misturado. Não volta a ser puro mais não"12. Já na formulação anterior, a volta é um caminho possível, como se pode notar. Mesmo com uma distância genealógica considerável: não importa de qual geração é um mestiço, se de terceira ou de quinta, sexta: se ele (um homem, suponhamos) se casar com uma india pura, o filho do casal voltará à segunda geração. Afinal, se assumimos sua linha de descendência materna como referência, o deslocamento é apenas de uma geração ${ }^{13}$.

Já os filhos de casamentos entre dois mestiços, continuam mestiços: afinal, um casamento entre iguais náo provoca nem distanciamento nem aproximação - da mesma forma que filho de dois índios puros é igualmente puro ou filho de dois tori é igualmente tori. Aqui encontramos uma diferença em relação aos cálculos desse mesmo tipo feitos pelos Karajá do Norte (Xambioá), em tudo semelhantes a este que descrevo aqui, exceto que, para esse outro grupo karajá, "o filho de mestiço com mestiço, para grande satisfação dos avós, igualmente, 'puxa mais pro puro"” (Cavalcanti-Schiel, 2008, p. 17) ${ }^{14}$.

Paralela às duas formulaçóes apresentadas, os Karajá utilizam ainda outra: o sangue ${ }^{15}$. Um mestiço traz consigo sangues diferentes, vindos tanto da mãe quanto do pai. É comum ouvir comentários do tipo "fulano, quer ver, já tem três sangues, Karajá, Javaé e Toril", falando de um mestiço cujo pai, por exemplo, seja um índio (mestiço de Karajá e Javaé) e a mãe seja tori.

Certamente esse esquema conceitual utilizado pelos Karajá tem relação com a forma pela qual concebem a descendência, como nota $\mathrm{Ca}$ valcanti-Schiel (2008, p. 16). Dada a reconheci- da bilateralidade do parentesco, alguns autores caracterizaram o sistema karajá como de dupla descendência, apontado para a dualidade entre uma afiliação matrilinear ao espaço doméstico aldeia (derivada ou associada a um padrão de residência uxorilocal) e patrilinear aos grupos rituais masculinos ijoi (cf. Lipkind, 1948; Dietschy, 1963, p. 44; 1978, p. 77; Donahue, 1982, p. 186-187; Pétesch, 1993, p. 373; Toral, 1992, p. 18; Fénelon Costa, 1978, p. 39). Entre os Javaé, segundo Rodrigues, apesar de a afiliação tanto aos grupos masculinos ijoi quanto ao espaço doméstico ser igualmente matrilateral (2008, p. 564), diferindo neste ponto dos Karajá, reconhece-se a "bilateralidade dos laços de descendência" (Op. cit., p. 521) - apesar de as contribuiçóes substanciais do pai e da mãe serem distintas. A descrição de Cardoso de Oliveira sobre os Ticuna nos fornece um contraste. Tendo a filiaçáo clânica, herdada patrilinearmente, como base para o reconhecimento étnico dos indivíduos, os casamentos entre mulheres ticuna com homens regionais implicou o não reconhecimento das crianças geradas por eles como pertencentes ao grupo, posto que náo possuíam um clá (1972). Parece claro que a forma particular de conceber a relação com maternos e paternos do ponto de vista da construção da pessoa está na base de tudo. Mas parece igualmente claro que "regras" de descendência não operam de forma mecânica, sendo antes a base a partir da qual tais cálculos são feitos. Sendo uma questão de parentesco, tudo depende da maneira como categorias (que implicam relaçóes determinadas) serão atualizadas, i.e., da construção do parentesco. Continuemos no exemplo de Cardoso de Oliveira: o autor descreve um caso de uma mulher ticuna que teve um filho com um mestiço, filho de mãe indígena e pai regional, um homem que, desta forma, não possuía um clã. $\mathrm{O}$ avô materno da criança, num esforço para incorporar seu neto ao grupo, solucionou o problema transmitindo para a criança o clá do avô de seu genro. Assim, 
De CORPOS DUplos | I I9

saltando uma geração, ele pode conferir uma filiação clânica a seu neto, fornecendo o meio para que ele fosse reconhecido como Ticuna, sem alterar a característica patrilinear da transmissão (Op. cit., p. 84-85).

Tenho aqui falado da mestiçagem como algo referente aos casamentos entre os Karajá e os tori. Mas o grupo tem também um longo histórico de intercasamento com os Javaé (embora isso sempre signifique uma parcela diminuta da população de uma aldeia), assim como com os Tapirapé. Independentemente de qual grupo estrangeiro está em questão, os Karajá fazem o mesmo tipo de cálculo. Assim, por exemplo, os filhos de meu anfitriāo na aldeia, Renan Wassuri, ele próprio um mestiço de Karajá e Javaé e casado com uma mulher javaé, são considerados Javaé puros. As questôes que a situaçấo de Buridina coloca para seus moradores náo são exclusividade da relaçáo com nosso próprio mundo. Somos um entre muitos Outros, afinal. Os comentários sobre a aldeia da barra do rio Tapirapé, onde quase todos são descendentes de casamentos entre Karajá e Tapirapé, mostram isso de maneira clara: as preocupaçóes com a continuidade da tradição, por exemplo, são basicamente as mesmas.

Apesar de em algumas conversas os Karajá terem chegado a elaborar as possibilidades de ca- samentos, tanto com tori quanto com puros, até a quinta ou sexta geraçóes de mestiços, a experiência cotidiana dos habitantes de Buridina é bem mais restrita. Há apenas três casamentos entre mestiços de terceira geração e regionais, sendo que apenas dois destes geraram descendentes, ou seja, crianças "de quarta geração" 16 . Isso ficará claro ao formarmos um quadro sobre a composiçáo dos casamentos atuais e antigos dessa aldeia ${ }^{17}$.

TABELA 1. CASAMENTOS ATUAIS

\begin{tabular}{|c|c|c|c|c|}
\hline \multicolumn{2}{|c|}{ casamento } & quantidade & & $\%$ \\
\hline \multicolumn{2}{|c|}{ Puro -Puro } & 4 & & 11,1 \\
\hline \multicolumn{2}{|l|}{ Puro-Tori } & 14 & & 38,9 \\
\hline \multirow{2}{*}{$\begin{array}{l}\text { Mestiço- } \\
\text { Tori }\end{array}$} & $2^{\mathrm{a}}$ ger. & 12 & 33,3 & \multirow{2}{*}{38,9} \\
\hline & $3^{\mathrm{a}}$ ger. & 2 & 5,6 & \\
\hline \multicolumn{2}{|c|}{ Mestiço-Puro } & 1 & & 2,8 \\
\hline \multicolumn{2}{|c|}{ Mestiço-Mestiço } & 1 & & 2,8 \\
\hline \multicolumn{2}{|l|}{ inỹ-ixỹju' } & 2 & & 5,6 \\
\hline \multicolumn{2}{|l|}{ Total } & 36 & & 100,0 \\
\hline
\end{tabular}

$\mathrm{Na}$ Tabela 1, vemos que a grande maioria dos atuais casamentos $(77,8 \%)$ envolve um cônjuge tori. Quanto aos casamentos entre dois

TABELA 2. CASAMENTOS ATUAIS POR FAIXA ETÁRIA

\begin{tabular}{|c|c|c|c|c|c|c|c|c|c|c|}
\hline \multirow{3}{*}{ Casamento } & \multicolumn{10}{|c|}{ Faixa etária } \\
\hline & \multicolumn{2}{|c|}{ Até 25 a. } & \multicolumn{2}{|c|}{ De 26 a 35 a. } & \multicolumn{2}{|c|}{ De 36 a 50 a. } & \multicolumn{2}{|c|}{ Mais de 50 a. } & \multicolumn{2}{|c|}{ Total } \\
\hline & quant. & $\%$ & quant. & $\%$ & quant. & $\%$ & quant. & $\%$ & quant. & $\%$ \\
\hline Puro -Puro & 1 & 9,1 & 0 & 0,0 & 1 & 9,1 & 1 & 33,3 & 3 & 8,3 \\
\hline Puro-Tori & 1 & 9,1 & 4 & 36,4 & 7 & 63,6 & 2 & 66,7 & 14 & 38,9 \\
\hline Mestiço-Tori & 9 & 81,8 & 4 & 36,4 & 2 & 18,2 & 0 & 0,0 & 15 & 41,7 \\
\hline Mestiço-Puro & 0 & 0,0 & 1 & 9,1 & 0 & 0,0 & 0 & 0,0 & 1 & 2,8 \\
\hline Mestiço-Mestiço & 0 & 0,0 & 0 & 0,0 & 1 & 9,1 & 0 & 0,0 & 1 & 2,8 \\
\hline inỹ-ixỹju & 0 & 0,0 & 2 & 18,2 & 0 & 0,0 & 0 & 0,0 & 2 & 5,6 \\
\hline Total & 11 & 100,0 & 11 & 100,0 & 11 & 100,0 & 3 & 100,0 & 36 & 100,0 \\
\hline
\end{tabular}

cadernos de campo, São Paulo, n. 19, p. 113-134, 2010 
puros, três deles estão em uma mesma família, a de Renan Wassuri, que morou 15 anos na Ilha do Bananal. O outro é o casamento do Cacique Raul, que casou com uma mulher da aldeia de Santa Isabel.

Na Tabela 2, temos os casamentos atuais distribuídos por faixas etárias. Tentei agrupar as idades de forma que correspondessem grosso modo às gerações da população atual. Esses números também dão suporte à afirmação feita acima, de que o início da mestiçagem, na década de 1970, corresponde ao estabelecimento de um novo padrão de casamento, pois em todas as faixas etárias, a maioria dos matrimônios envolve cônjuge tori (até 25 anos - 90,9\%; de 26 a 35 anos $-72,8 \%$; de 36 a 50 anos $-81,8 \%$; mais de 50 anos $-66,7 \%$ ).

O principal motivo alegado pelos Karajá para terem começado a casar com os regionais era a impossibilidade de se casarem entre si devido à proximidade dos laços de parentesco. Mesmo atualmente, quando se pergunta sobre os matrimônios dos atuais jovens, essa é uma resposta dada: "É todo mundo parente". Algumas vezes, entretanto, quando insistia, perguntado se ainda hoje seria possível dizer isto, mesmo a aldeia tendo crescido, a questão tomava outro rumo. "É, agora já pode casar, porque já distanciou um pouco", me dizia uma mulher. Mas mesmo que "a distância tenha aumentado um pouco", tornando possível a endogamia de aldeia, os jovens vão continuar casando com tori, ela concluiu. Leite (2007) já havia registrado a diferença de comportamento social entre os jovens de Buridina e das aldeias da Ilha do Bananal como um empecilho para as unióes entre ambos: os primeiros são vistos pelos segundos como "muito tori" e os segundos pelos primeiros como "muito tradicionais". "Ambos os grupos indígenas consideram as respectivas aldeias muito diferentes no seu modo de vida e acreditam não se acostumar se tivessem de viver fora de sua aldeia de origem" (Op. cit., p. 37).
Para além, entretanto, de pensar as impossibilidades de se casarem entre si ou os empecilhos de o fazerem com seus parentes da ilha, o que interessa aqui é ver esse fenômeno a partir de suas próprias motivaçóes e características. Os Karajá de Buridina casam com tori porque "estão acostumados com outra forma de namorar", como disse uma mulher e, diria eu, de casar, de criar seus filhos, de "ganhar a vida", de construir parentesco e pessoas, etc. Hoje, os Karajá dizem não haver problema que os jovens se casem com não índios, desde que, com isso, náo deixem de devotar a devida atenção à cultura e tradição karajá. Em Portela (2006, p. 169) encontramos um exemplo dessa postura em uma fala de um indígena citada pela autora: "Mas o meu caso é mais tentar fazer que a aldeia mantenha sua cultura, num importa que tá casando com não índio, não importa não, porque as duas coisas são importantes".

Também o Cacique Raul me dizia que, "no meu modo de ver, não tem jeito de parar os meninos de casar na cidade. Contanto que mantenha a cultura, pode casar [com tori] à vontade!".

\section{Vai misturando, vai acabando: mas "a mistura não tem problema, não"}

Mistura é o termo utilizado pelos Karajá para se referir aos casamentos com não índios (ou outras categorias de Outros) e a uma série de processos a eles relacionados. Ela é a explicação oferecida para uma série de coisas taxadas pelos regionais como "aculturação", como a perda parcial da língua e mudanças de certos padrôes de pensamento e nos "costumes" (da produção para o consumo à produção para venda, por exemplo). Quando conversava com uma senhora karajá, por exemplo, sobre a história da aldeia, ela começou a falar sobre como tradicionalmente se dava o casamento karajá1 ${ }^{18}$, dando o exemplo de seus pais, para em seguida 
fazer um comentário sobre o estado atual das coisas.

Agora não estão casando mais assim, não, por que acabou a tradição, acabou, não tem mais... Agora casa aí de qualquer jeito. Porque casamento mesmo, igual minha mãe casou com meu pai... acabou também, não tem mais. Só se for lá pra Ilha [do Bananal], é capaz que ainda tem esse casamento assim. Mas está acabando tudo, essas coisas. E agora pior vai ficar, por que está misturando muito! Aqui, quem é puro aqui em casa é só eu. Já meus netos, meus filhos, já são todos mestiços.

Também os conflitos familiares na aldeia são associados aos casamentos com tori, um casamento, afinal, distante - e, nesse sentido, indesejado -, que tem como uma de suas consequências o não reconhecimento dos parentes. Assim, alguns dizem que o motivo das brigas é o não reconhecimento das relações de respeito, evitação, etc., implicadas nos laços de parentesco. Quando conversava com um índio vindo de uma aldeia da Ilha do Bananal, ele se queixava para mim de seu estranhamento em relação a Buridina: "É difícil! Misturou muito, não tem mais o costume". Essa descaracterização é imputada também aos mestiços, em certas ocasiōes. Um homem me relatava um caso de um jovem que havia levado um amigo não indígena para pescar em um lago dentro da reserva. Perguntei se o rapaz era índio, ao que ele respondeu que sim, para depois complementar: "mas é de quarta geração, já não tem quase mais nada de Karajá".

A mestiçagem, entretanto, não é algo exclusivo de Buridina, podendo-se encontrar mestiços em muitas aldeias da Ilha do Bananal - mesmo que em menor quantidade -, e a maneira como os Karajá de Buridina falam sobre eles nos traz uma consideração importante. Um senhor me contava sobre dois exemplos. O primeiro caso, o de dois rapazes negros, altos e fortes. O segundo, o de duas meninas loiras, bonitas e de cabelo liso e comprido. Em ambos os casos, apesar de a fisionomia não apresentar características indígenas - "você olha, assim, e não tem nada de índio" -, os mestiços em questão dominavam bem "as duas linguagens". No caso das meninas, com 13, 14 anos, estavam de férias na aldeia, se pintavam e dançavam com Aruanã. "Deram um show". Quando o pai (tori, com quem moravam) foi buscá-las, não quiseram voltar para a cidade com ele. Acabaram ficando na aldeia e se casaram por lá. A despeito de sua fisionomia (a "característica") destoante da maioria dos indígenas, esses mestiços falam as duas línguas e "conhecem a cultura", i.e., participam dos rituais, conhecem histórias, topônimos, utilizam a terminologia de parentesco, etc. Assim, aos olhos dos Karajá de Buridina, sua ascendência misturada não é suficiente para os diminuir frente a seus parentes puros. Isso me suscitou a ideia de que os mestiços, antes que pessoas a meio-caminho, sem identidade "Um mestiço. Nem branco, nem índio. Nada" (Vasconcelos, 1965, p. 13) - eram pessoas de certa forma privilegiadas nessa empreitada de conhecer "os dois lados". Tendo um pai tori e uma mãe inỹ, por exemplo, "viria desde pequeninho", como dizem os Karajá, conhecendo tanto a cultura indígena como a dos brancos. Rodrigues, por exemplo, menciona que os mestiços, "produto recente de uma uniáo entre membros de grupos étnicos diferentes, podem apelar para os dois princípios, separadamente, ou mesmo ter as duas identidades" (2008, p. 559). Mas, curiosamente, quando perguntava isso aos índios de Buridina, eles diziam que não, os mestiços cresciam sabendo mais da cultura tori, "puxando mais para o lado dos brancos". Mas quando eu replicava "e na Ilha [do Bananal]?", as respostas mudavam. "Na Ilha, não. Aí, pra pessoa, capaz que é mais fácil [de conhecer ambos os lados], não é? Porque a mãe é índia e o pai é branco, então vai saber falar as duas línguas", um homem me disse. 
Assim, quando os Karajá de Buridina dizem que "a cultura/tradição está acabando, porque misturou muito”, o que está em foco não é a mestiçagem em si, mas a forma especifica que este processo vinha tomando nesta aldeia desde a década de 1970, com o início dos casamentos misturados: um privilégio da perspectiva dos tori. E, em algumas ocasióes, os Karajá assim o reconhecem. Uma mulher, por exemplo, me contava sobre o caso da roça comunitária do município, que não tem funcionado muito bem, pois se, por exemplo, trinta pessoas se inscrevem para participar, na hora de trabalhar na limpeza do cultivo, na hora de roçar, menos de dez compareciam. E comentou que "o pessoal diz que é assim porque misturou. Mas não é não, lá na Ilha [do Bananal] é a mesma coisa”.

A questão que se colocam hoje os Karajá nessa aldeia é o desafio de reverter esse privilégio da perspectiva tori em seu cotidiano, um processo que eles têm rotulado como "resgate cultural". Processo este, entretanto, que não é uma volta, um retorno a uma situação anterior, mas sim um reforço da perspectiva indígena, dizem os Karajá, pois "as duas coisas se complementam, a cultura do índio e do não índio, os dois lados são importantes". Como no caso dos Wari', os Karajá não querem "voltar para 'o mato", i.e., afastar-se dos brancos e de sua perspectiva para viver simples e exclusivamente como Karajá ou Wari'19, "e explicitam que estar junto dos Brancos é uma opção deles" (Vilaça, 2000, p. 69). Eles querem e buscam ativamente ser dois. "Ao dizerem que sáo 'brancos completamente', os Wari' não entendem que estão perdendo sua tradição, ou sua cultura, como poderíamos pensar”, o que também podemos dizer dos Karajá, "o que acontece é que têm agora a experiência de um outro ponto de vista" (Vilaça, 2006, p. 512). Não se está interessado em saber apenas sobre o mundo karajá. Muito pelo contrário - embora seja fundamental conhecê-lo muito bem. "Nós somos seres huma- nos que têm outras culturas e outros costumes, me vejo como índia que tenho duas culturas: Karajá e não índio", como disse uma mulher de Buridina (Portela, 2006, p. 197). O próprio "resgate cultutal" é, assim, algo que supóe a coexistência de ambos "os lados", as perspectivas indígena e não indígena. A questão problemática, portanto, não é a mistura em si. A resposta que Renan Wassuri deu à pergunta que lhe fizeram num curso de formação de professores indígenas é emblemática nesse sentido. Uma índia de outra etnia lhe perguntou: "O que você acha da mistura?", falando sobre os casamentos com brancos. Ele próprio me relataria a pergunta e sua resposta, depois do acontecido.

A mistura não tem problema, não. Porque todos nós, seres humanos, somos assim, misturados. Para mim, não importa a característica, se é de índio, se não é. Importa é ele saber quem ele é, filho de índio. Então, para ele, as duas coisas são importantes, tanto o conhecimento do índio como o do não índio. As duas coisas são importantes para nós, como para nossas crianças. $\mathrm{O}$ meu lado direito [do cérebro] pode ser inỹ, o esquerdo é tori!

Em outra ocasiáo, conversando ainda com Renan sobre os mestiços na Ilha do Bananal, tendo ficado evidente para mim que a questão problemática em Buridina não era a mestiçagem em si, mas a dificuldade de se acessar a perspectiva indígena, perguntei entáo como seria se todos em Buridina soubessem falar o inỹrybè, soubessem cantar e dançar nas festas, conhecessem as narrativas míticas, enfim, "conhecessem a cultura"? Ainda assim a mestiçagem seria um problema? "O importante para nós é guardar a cultura na memória, no sangue", me respondeu. "Náo importa que a mãe ou o pai não seja índio?", continuei. "Pode ter o olho azul, não importa”. Com efeito, na maior parte dos comentários sobre os mestiços na Ilha do Bananal, os Karajá de Buridina se mostravam impressio- 
nados pela sua capacidade de falar as duas línguas ou de participar ativamente na vida ritual do grupo. O que os encanta, parece-me, é a equidade que esses outros mestiços estabelecem entre "os dois lados" - levando até o fim sua constante afirmação de que "os dois lados", ou "as duas coisas", são igualmente importantes -, justamente a questão à qual os Karajá de Buridina têm hoje se dedicado.

Em Buridina, há um acoplamento discursivo da mestiçagem ao lado da mistura que se mostrou historicamente problemático para eles. Um acoplamento, porém, que é apenas discursivo, no sentido de que o que se mostra problemático de fato não é a mistura em si, mas a forma peculiar desse processo histórico, como dito. Eles, porém, direta ou indiretamente, reconhecem que essa é apenas uma possibilidade de desenvolvimento do processo de mistura. $\mathrm{O}$ que os interessa, hoje, é a reversão desse desequilíbrio: a eles não interessa deixar de viver como brancos, mas sim a possibilidade de viver tanto a vida dos tori (virar branco) quanto a dos Karajá - i.e., a possibilidade de ser ambos sempre que quiserem ou precisarem. Algo que só se pode fazer se houver uma mínima equalização do acesso a ambas as perspectivas.

\section{Da mestiçagem à mistura}

Voltemos aos comentários que associam a mistura à "perda da cultura". Prestando-se atenção a quem são endereçados comentários como aqueles, percebe-se que muitas vezes eles náo se referem exclusivamente a mestiços. Em diversas ocasióes dizem que, "hoje em dia", os jovens não se interessam mais por certas questóes culturais, como a ética de respeito referente ao relacionamento com parentes e afins (e, portanto, ao uso da terminologia de parentesco) ou as práticas de resguardo, por exemplo. A fala de um indígena, hoje falecido, que Portela cita em sua dissertação nos serve de exemplo.
Mas, como os meninos de hoje não tão querendo aprender o que nós, o que nossos avôs usavam, tão puxando mesmo é só pro lado dos brancos, então ficou difícil pra nós, porque nós já tá no meio da cidade mesmo, os meninos já veio falando foi o português mesmo, não fala assim nossa linguagem... (2006, p. 186).

Ora, portanto, os Karajá falam que "está acabando" porque "misturou" ou "está misturando", ora falam que "está acabando" devido à falta de interesse dos jovens. Poder-se-ia dizer que essas duas explicações nada mais são, na verdade, que formas alternativas de dizer a mesma coisa, pois a grande maioria dos jovens de Buridina é mestiça. Mas outro exemplo indica que não parece ser este o caso. Eu conversava com um homem (puro) - que veio com sua família da Ilha do Bananal para Buridina há pouco mais de seis anos - sobre os jovens, que são muitos ligados ao hábito de assistir televisão, gostam de ir para as festas na cidade, fazem amigos tori e circulam com eles pelas ruas de Aruanã, etc., ao que ele comentou sobre seus próprios filhos - todos puros: "Lá em casa já está misturando também!". Ele não falava das relações conjugais de seus filhos, pois são todos solteiros, mas de um processo de conhecimento e experimentação do mundo não indígena. A fala de Renan Wassuri citada anteriormente também nos serve de exemplo. Ele é um indio puro que mora com outras dezesseis pessoas na mesma casa, entre sua esposa, filhos, netos e genros, todos puros - exceto um dos genros, mas o casal ainda não teve filhos. Seus pequeninos netos falam a língua indígena, e só agora, com três, quatro ou cinco anos, começam a compreender melhor o português e a aprender a falar algumas palavras de nossa língua. Quero chamar atenção, ao dizer isso, para o salto que há em sua fala da terceira pessoa do singular ("Importa é ele saber quem ele é") para a primeira pessoa do plural ("As duas coisas são importantes para nós"): ele inicia o trecho falando sobre os 
mestiços, mas muda o foco repentinamente sobre todos "nós", mas ainda tematizando a mistura. Além do mais, "todos nós, seres humanos, somos assim, misturados". A oscilação presente nas falas entre "jovens" e "mestiços", assim, parece apontar que o que está em foco não são os mestiços, e sim a mistura. Ela, portanto, é uma questão tanto para mestiços quanto para puros, algo bem mais geral e que caracteriza a experiência urbana - i.e, tori $^{20}$ - dos Karajá de Buridina. A mistura é uma linguagem mais ampla que a mestiçagem.

\section{Uma aldeia karajá}

Apesar de a experiência - sobretudo dos mais jovens - com a mistura apresentar um aspecto visto como problemático, expresso geralmente em termos de um privilégio do ponto de vista dos brancos, a perspectiva dominante na aldeia é a dos inỹ. Num curso de formação de professores indígenas, perguntaram a Renan Wassuri o que ele achava de sua aldeia. Sua resposta foi a seguinte.

É muito bonita! Poderia ser mais, mas ainda assim é bonita. E ainda é uma aldeia mesmo! Estamos aqui [no centro da cidade], a sociedade conhece nós, nossas crianças. Ainda é aldeia. No dia que descontrolar, aí vai virar setor [da cidade] descendente de Karajá, porque aí acabou, né? Mas ainda é aldeia, aldeia mesmo!

Certa vez, perguntei ao Cacique Raul se poderíamos dizer que a conjugaçáo entre aldeia e cidade seria uma característica de Buridina, pensando justamente na relação de conhecimento privilegiada em relação ao mundo tori, reconhecida por seus parentes da Ilha do $\mathrm{Ba}$ nanal quando estes os chamam de tori hãwa mahãd $u^{21}$, ao que ele respondeu de pronto e categoricamente: "Não. O ritmo da aldeia é normal, como qualquer outra”. Apesar de estarem no meio da cidade, tori hãwa, aldeia/território/ lugar dos brancos, Buridina mantém-se como inỹ hãwa, "aldeia mesmo". É um processo que teve pontos baixos e bastante complicados, mas que hoje se vê transformando para melhor.

Em relação especificamente aos mestiços poder-se-ia dizer a mesma coisa. Se em certas circunstâncias podem-se ouvir críticas a respeito deles, como que "puxam mais para o lado dos brancos", que "não sabem falar a língua", que "não sabem contar história pros filhos" (cf. [Cavalcanti-]Schiel, 2002, p. 50), em outros momentos ouvem-se as mesmas pessoas falarem dos mestiços de outra forma: "fulano, que é índio...", "de índio lá tinha fulano e sicrano...", ou, como certa vez disse um homem a seus parentes da Ilha do Bananal, que estavam em Aruanã a passeio, irritado com seus comentários - sobretudo das crianças - sobre a ascendência tori dos Karajá de Buridina, "aqui todo mundo é índio!"

Se todos nessa aldeia têm um nome em português (geralmente escolhido por um ou ambos os pais da criança), todos também têm seu nome indígena, e a nominação é algo sobre o que dificilmente poderíamos traçar distinçôes drásticas entre esta e outras aldeias. Uma criança, ao nascer, recebe um estoque de nomes. Cada um dos quatro avós pode transmitir seu próprio nome ou de um de seus pais ou tios, mas apenas um destes se fixará, e é por ele que a pessoa será conhecida ${ }^{22}$. Não há nenhuma cerimônia de nominação ${ }^{23}$. Se uma pessoa é muito idosa e bastante respeitada, ela pode dar nomes para outras crianças que não seus próprios netos. Em Buridina, assim, em alguns casos nos quais os avós da criança já haviam falecido, o pai ou mãe indígena da criança procura uma das pessoas mais idosas e respeitadas da aldeia para que a criança ganhe um nome. Talvez mesmo como consequência disto, o estoque de nomes de uma pessoa vê-se assim reduzido, restringindo-se, muitas vezes, a um único nome.

Também sobre a mistura pode-se ouvir discursos aparentemente contraditórios de uma 
mesma pessoa. Sentado no sofá da sala de uma senhora, ela me falava de uma de suas avós ${ }^{24}$, filha de um português que era comandante de um dos vapores que navegou no Araguaia, bem como de outros ascendentes, javaé e tapirapé. E concluiu: "Então nós temos quatro sangues misturados, nós não somos Karajá puro, puro, mesmo". A essa altura eu já pensava comigo que isso não impedia que em outros momentos ela se dissesse (e apontasse outras pessoas como) india pura. Aqui não poderia deixar de lembrar a etnografia piro de Peter Gow (1991). Também ali não há contradição entre ser de sangre mezclada e Piro, simplesmente. Os paradoxos identitários, sabemos bem, muitas vezes estão mais na cabeça dos antropólogos do que na das populações estudadas. O que em um nível é um de dois termos homogêneos (os Karajá puros, em oposição aos não Karajá/não índios) relacionados um ao outro por um meio (os mestiços), em outro nível é o próprio meio que relaciona dois outros extremos (dois povos ixỹju, estrangeiros) ${ }^{25}$. Como que lendo meu pensamento, ela prosseguiu dizendo que, talvez, pensava ela, o sangue dos tori e dos Javaé fosse mais forte que o sangue karajá, e usou como exemplo um mestiço karajá/javaé. "O Renan, por exemplo, é mestiço de Karajá com Javaé. Ele puxou mais pro Javaé. Ele, as filhas dele... se bem que as filhas dele já são Javaé puras, porque a mãe é Javaé e o avô também era...”.

O mundo ameríndio, sabemos, é altamente transformacional, como nos mostram as mitologias dos diversos grupos das terras baixas sul-americanas (e alhures). Essas mitologias, poder-se-ia dizer, são mesmo o modelo (sociocosmo)lógico da transformação (dos corpos-perspectivas). Mas a mudança, a transformação, no mundo ameríndio, difere da forma como nós próprios a pensamos, pois, se para nós a identidade é uma medida de continuidade consigo próprio, algo que não pode ser revertido facilmente, do ponto de vista indígena o ser é muito mais um transformar-se, onde a forma é sempre provisória (cf. Viveiros de Castro, 2002a). Só se transforma, num sentido, porque se pode voltar: a reversibilidade é justamente uma característica desse processo. O grupo que ficou conhecido na literatura etnológica como Suyá, autodenominado Kïsêdjê, fornece-nos um exemplo interessante.

Tendo adentrado a bacia do rio Xingu há pelo menos duzentos anos, esse grupo jê foi se integrando parcialmente ao sistema alto-xinguano. "O mais importante efeito dessa participaçẫo foi o que se pode chamar a "xinguanização" dos Kïsêdjê, em diversos planos: no da tecnologia e cultura material; na ornamentação corporal e na fabricação dos corpos; no repertório musical e cerimonial" (Coelho de Souza, 2009, p. 3). Em 1969, depois de uma malsucedida tentativa de "pacificação", os 41 sobreviventes dos Tapayúna (grupo muito próximo linguística e culturalmente) foram alocados junto aos Kisêdjê. "Sua chegada mudou consideravelmente a ênfase da cultura suyá. Eles olhavam, falavam e agiam como os ancestrais suyá' (Seeger, 1980, p. 165), e tal evento provocou uma iniciativa de revitalização da sua cultura anterior à entrada na bacia do Xingu, i.e., sua cultura jê. Assim, "do ponto de vista kïsêdjê, não apenas essa aculturação não é um processo finalizado ou finalizável, como tampouco se trata de algo irreversível" (Coelho de Souza, 2009, p. 4). Outra "pressão aculturativa”, a resultante da intensificação das relaçóes com a sociedade não indígena, com seus objetos e com seu conhecimento, tem provocado resultado semelhante:

O momento é de intensa, ainda que ambivalente, experimentação: de um lado, emerge uma espécie de 'fundamentalismo cultural' que orienta uma série de açóes 'depurativas' no sentido de manter o caráter 'jê' da sua 'cultura', em oposição às culturas xinguanas, e 'indígena', em oposição aos brancos; de outro, um desenfreado esforço de aquisição desses bens e recursos alienígenas (Op. cit., p. 5). 
Um mestiço, assim, pode ser branco ("puxar mais para o lado do branco") em um momento e índio em outro, sem que isso seja uma contradição, assim como um indio puro pode ser puro em um momento e misturado em outro, ou um xamá pode ser Karajá em um momento e sucuri em outro, humano em um momento e não humano ${ }^{26} \mathrm{em}$ outro.

\section{Uma aldeia misturada}

Buridina, como já deve ter ficado evidente, é uma aldeia dividida, por assim dizer, uma aldeia misturada, na qual para tudo há dois lados, duas formas de se contar a mesma história. Detenhamo-nos um pouco sobre alguns exemplos dessa dualidade.

A começar pelo nome da aldeia. Alguns afirmam que é uma corruptela do antigo nome da cidade (Leopoldina). Outros, entretanto, dizem que Buridina é uma aproximação para o português do verdadeiro nome da aldeia em inỹrybè: burudena hãwa, termo cuja tradução aproximada seria "lugar onde há muita concha buru".

À diferença das outras aldeias karajá e javaé, as duas fileiras de casas de Buridina têm suas portas frontais orientadas para sentidos opostos: uma das fileiras está virada para o rio; a outra, para a principal avenida da cidade (que está, portanto, no lugar do rio para esta fileira de casas) - cf. também Cavalcanti-Schiel (2008, p. 18).

Come-se tanto comida inỹ quanto tori. A base da dieta alimentar é arroz e feijáo e, muitas vezes, farinha, produtos, via de regra, comprados no comércio local. Assim, o que diferencia a "comida de índio" da "comida de tori" é a carne da refeiçẫo. Assim, se a carne é vermelha (de gado ou de porco) ou frango, trata-se de "comida de tori", ao passo que peixe ou tartaruga caracterizam a "comida de índio". Se as primeiras carnes são compradas, as segundas são fruto da pesca indígena.
Fala-se tanto a língua indígena quanto o português, e todos têm um nome não indígena e um nome inỹ. Algumas pessoas ficaram conhecidas, quando se fala em português, pelo nome tori, outras pelo nome indígena. Mas é a língua que se está falando que geralmente determina a forma como se refere a determinada pessoa. Assim, por exemplo, eu conversava com Kari sobre Jacinto $\mathrm{Ma}(\mathrm{k})$ urehi. Ela se referia a ele como tio Jacinto, como quase todos os mais velhos da aldeia o fazem. Em determinado momento, ao não se lembrar de um detalhe da história que contava, consultou sua irmã mais velha, que estava conosco na hora. Ao conversar em inỹrybè com ela, entretanto, Kari se referiu a seu tio como Makurehi.

Patrícia Rodrigues evoca a situação da aldeia txuiri, na qual, "enquanto o prenome brasileiro é escolhido pelos pais da criança, no seu nascimento, os nomes (série nominativa) karajá são sempre atribuídos segundo o seu próprio sistema de nominação" (Bonilla, 1997, p. 90 apud Rodrigues, 2008, p. 687), algo que também ocorre entre os Karajá de Buridina. Disto, a autora conclui que "a lógica antiga da nominação é reapropriada diante de uma nova realidade, de modo que o nome 'estrangeiro' é dado pelos genitores de corpo aberto, enquanto os nomes 'ancestrais' são dados pelos avós de corpos fechados" (Rodrigues, 2008, p. 687), o que está associado a uma série de contrastes básicos em sua leitura da sociocosmologia javaé, cujos termos principais, no que interessa aqui diretamente, seriam alteridade, transformaçáo e corpos abertos, de um lado, e identidade, estatismo/permanência e corpos fechados, de outro. A coerência da duplicidade dos nomes e da nominação entre os Karajá de Buridina me parece, entretanto, poder ser explicada de outra maneira. Se os nomes iny, como vimos acima, são transmitidos da maneira tradicional, a atribuição dos nomes tori (que, note-se, não são transmitidos, mas "dados") segue a tra- 
dição dos brancos: dá-se nomes tori aos filhos, em suma, da mesma maneira que os tori eles próprios o fazem. Este seria, portanto, mais um aspecto misturado de Buridina.

A escola é dividida em dois turnos: pela manhã as crianças têm aula da língua indígena; à tarde, estudam as matérias do currículo do sistema de ensino público estadual - português, matemática, história, geografia, inglês, etc. -, ao qual a escola indígena foi integrada. Eles se referem às aulas matutinas como "aulas de inỹrybe" e às aulas vespertinas como "aulas de torirybe", i.e., a fala, modo de falar ou língua dos tori.

Há o reconhecimento de que aldeia e cidade são marcadas por distintas socialidades, que náo se confundem. Dizem que a cidade tem suas "leis", falam "na lei da cidade", na "lei do branco", a "organização lá de fora”, utilizando estes termos para contrastar com a "cultura", o "jeito cultural", o "nosso jeito" ou a "lei do índio". "Pela lei do branco é assim, mas na cultura é diferente". Ou, como Renan certa vez me explicou:

Quando a gente vai pra cidade, quando atravessa o portáo [da aldeia] ali, tem que tirar a memória indígena, guardar no bolso e colocar a memória de não índio no lugar [gesticulando com as máos como se tirasse e colocasse pequenos chips de memória em sua cabeça]. Quando chega pra cumprimentar alguém é "bom dia", "como vão os senhores?", se for uma mulher abraça e dá um beijo no rosto, ou entáo dá um beijo nas costas da máo. Aí vão saber que quem está ali é um cavalheiro. Porque os índios não se cumprimentam assim, é na distância, não se encostam. Aí quando passa do portáo pra dentro tem que tirar a memória do não índio da cabeça e colocar a memória indígena, que estava guardada [no bolso], no lugar. Aí volta a funcionar do nosso jeito. Entáo a gente tem que ter essas duas memórias, e as duas são muito importantes pra gente.
Aqui vemos claramente que cada "memória" está relacionada a um espaço (aldeia/cidade) e a uma socialidade (indígena/não indígena).

Para todos nessa aldeia, os brancos são tanto parentes quanto Outros, uma dualidade que se constitui em alguns momentos como uma tensão. Todos têm tori em suas famílias e, assim, entretêm com eles relaçóes de parentesco - sobretudo como pai/mãe ou, segundo a tecnonímia karajá ${ }^{\bigotimes}$, "pai/mãe do meu neto(a)", i.e., genros e noras. Por outro lado, a incapacidade desses parentes tori de se comportarem como parentes verdadeiros, sendo muitas vezes avarentos, preguiçosos ou mesmo utilizando o matrimônio interétnico como suporte e/ou justificativa para cometer infraçóes legais como pesca sob condiçóes ilegais ou extração de madeira da reserva indígena, por exexemplo -, marca sempre, aos olhos dos Karajá, seu lado Outro ${ }^{28}$. Certa vez, eu conversava com um homem, quando ele fazia muitas reclamaçóes sobre o comportamento desses tori, dizendo que, se fosse na Ilha do Bananal, a comunidade já os teria expulsado. Perguntei, então, porque isso náo acontecia aqui, ao que ele respondeu: "Não sei. E se falar alguma coisa, acha ruim. A menina acha ruim porque é o marido dela, a mãe acha ruim, também, porque é o genro dela, vai falar que ele está fazendo aquilo para sustentar a filha dela".

\section{De corpos duplos}

Voltemos aos cálculos da mistura, cujas formulações foram apresentadas no início do texto. Seriam aquelas equaçóes genealógicas e sanguíneas uma teoria genética da inter-relação cultural? Certamente não, mas certamente sim. Explico-me. Certamente não, se o que temos em mente são tipos similares de explicação (sociobiológicas, sociogenéticas) que ainda hoje podemos encontrar em nosso próprio mundo. Por outro lado, não pretendo dizer, com isso, que a 
explicação indígena seja metafórica, que falam de corpo querendo dizer outra coisa: trata-se sim de uma teoria corporal. Apenas seus corpos são diferentes dos nossos (cf., por exemplo, Viveiros de Castro, 2002b; Vilaça, 2005). As teorias sociais ameríndias são tão corporais quanto suas teorias corporais são sociais: mais precisamente, essa distinção [entre o corpo (natural, dado) e relaçôes sociais (construídas)], clássica entre nós, não existe entre eles, como bem mostra Patrícia Rodrigues para o caso javaé.

Tudo aquilo que no Ocidente está localizado "fora" do corpo - na alma, na psique ou no intelecto - e que constitui o sujeito abstrato, seja a inteligência ou o pensamento, a sensibilidade artística ou as emoçóes, a criatividade conceitual ou as imagens oníricas, a consciência ou o inconsciente, para os Javaé está profundamente "dentro da carne", é imanente à matéria de que é constituído o corpo humano. Não se trata meramente de uma não oposição entre emoção (sentimentos) e razão (pensamentos), ambos situados dentro do $k y$, mas de uma inadequaçáo total da clássica oposição entre os atributos e produtos do corpo e os atributos e produtos da mente/alma, entre o concreto e o abstrato, entre o material e o sutilmente invisível, entre o biológico e o conceitual. (...) Em suma, o sujeito humano não é uma abstração racional ou imaterial, mas antes de tudo um corpo (Rodrigues, 2008, p. 406-407).

Se a distinção entre atributos da mente e atributos do corpo não nos ajuda a melhor compreender o que se passa no mundo ameríndio, nossas noçôes sociais (e mentais) de mudança e relação cultural também tampouco o fazem. Uma mudança social, para os ameríndios, apresenta sempre um correlato corporal, ou melhor, é sempre ela própria corporal: "não há mudança espiritual que não passe por uma transformação do corpo, por uma redefinição de suas afecções e capacidades" (Viveiros de
Castro, 2002b, p. 390). O que poderíamos dizer, então, sobre o caso dos Karajá?

"Eu valorizo muito os dois lados. Não valorizo só a nossa cultura, não só a do branco: uma complementa a outra", dizem constantemente os Karajá. Um homem, por exemplo, criticava a atitude de algumas pessoas da aldeia porque, quando morre alguém, "eles fazem é levar padre lá pra rezar". Ele disse não concordar com isso por não se estar fazendo "do jeito cultural". O correto, prosseguiu, era que as duas "religióes" (como ele dizia) estivessem presentes, não só a dos tori: "a cruz e o $i$ txe $(k) \dot{\partial}^{\mathbb{\Phi}}$, tem que ter os dois, mas o corpo é um só”. $\mathrm{Ou}$, como ele próprio havia me dito em outra oportunidade, "minha característica é indígena, mas eu uso duas coisas ao mesmo tempo, característica, língua...”. Se a mistura, para os Karajá de Buridina, como argumentei, é um dois sem intervalo, uma duplicidade na qual só se pode estar de um dos lados - sob uma das perspectivas - a cada momento, o aspecto corporal desse fenômeno só pode se apresentar também como uma duplicidade. Vejamos o caso dos xamás wari', que nos fornecerá uma imagem deste ser dois.

Tudo começa com uma doença por jamikarawa, ou seja, quando uma pessoa é acometida pelo "espírito" de um animal, que leva consigo a "alma", jam, da pessoa. Se não houver uma cura xamânica, recuperando o jam da pessoa, ela morrerá e se transformará em um animal da mesma espécie daquele que a agrediu. Esse, entretanto, não é o único destino possível: pode-se estabelecer uma relação com os espíritos animais, adiando, assim, o momento em que se torna um igual, um consubstancial, do animal em questão. É assim que se torna xamá. "Na doença iniciatória, o xamá dorme e sonha com karawa, que ele vê com a forma humana, como um igual. É durante o sonho que ele será banhado por jamikarawa e se sentirá 'curado', com melhor disposição física" (Vilaça, 1992, p. 82). Depois do banho, os jamikarawa oferecem ao xamã uma esposa, o que estabelece entre eles 
uma relação de aliança. $\mathrm{O}$ casamento, entretanto, só será consumando posteriormente, quando sua esposa "se tornar moça". A consumação do casamento corresponderá à morte do xamá frente a seus parentes humanos e à sua transformação definitiva em um jamikarawa. Com o banho, "o jam [do xamã] torna-se karawa [ani$\mathrm{mal}$, e com isso o processo de desaparecimento do corpo físico (doença-morte) é interrompido; o agora xamã se torna um doente crônico, um wari' com jam autônomo, um homem-animal" (Op. cit., p. 83). “Tudo se passa como se o xamá tivesse dois corpos: um humano, entre os Wari', e outro animal, junto aos animais" (Op. cit., p. 80). "Diz-se que o xamá jamu, ou seja, por meio de seu espírito, ele se transformou e passou a ter um outro corpo" (Vilaça, 2006, p. 203) ${ }^{30}$.

A relação dos Wari' com os brancos se daria de maneira similar: assim como o xamã não deixa de ser wari, humano, quando ele jamu, i.e., quando sua "alma" torna-se um corpo animal, o conhecimento e a experimentação do mundo dos brancos constituem-se como um outro corpo-perspectiva possível, que não exclui seu ponto de vista indígena. Nas palavras da autora:

Eu diria que os Wari' querem continuar a ser Wari' sendo brancos. Em primeiro lugar, porque desejam as duas coisas ao mesmo tempo, os dois pontos de vista. (...) Os Wari', pelo que entendo, não querem ser iguais aos brancos, mas mantê-los como inimigos, preservar a diferença sem, no entanto, deixar de experimentá-la. Nesse sentido, vivem hoje uma experiência análoga à de seus xamâs: têm dois corpos simultâneos (Op. cit., p. 515; Vilaça, 2000, p. 69).

As conclusóes às quais a autora chega, percebe-se logo, vão precisamente ao encontro da descrição que faço aqui - exceto no que concerne aos Wari' não casarem com seus Outros (e isto, quando ocorre, anular a diferença em questão) e os Karajá o fazerem ${ }^{31}$.
Também para os Karajá de Buridina, a relação entre seu próprio ponto de vista e o dos tori, mediada pelos casamentos misturados, se constitui como uma questáo corporal: a possibilidade de uma experiência dupla (o ser dois, poder acessar dois pontos de vista, como faz o xamã) corresponde a uma duplicidade dos corpos. Não se trata, porém, de algo que é viabilizado por um corpo duplo, mas de algo que o corpo duplo é: uma experiência dupla. Assim, para os Karajá, segundo percebo, essa relação é o próprio corpo mestiço. Note-se que quando falam dos sangues de uma pessoa mestiça, por exemplo, os Karajá não falam de um sangue misturado, como no caso piro (Gow, 1991), mas dos dois (três, quatro...) sangues da pessoa. "Então nós temos quatro sangues misturados", me dizia uma senhora. Ou quando eu conversava com um homem sobre os possíveis futuros filhos de uma jovem mestiça (cujo pai era mestiço de Karajá e Javaé) casada com um índio xerente, ele comentou que "a criança já vai ter, quer ver... quatro sangues: karajá, javaé, tori e xerente". Uma perspectiva-corpo misturada não funde os corpos-perspectivas que lhe dão origem: ela apenas os póe em relação. $\mathrm{O}$ mestiço, a mistura, parece encarnar justamente essa relação. Não um um (um único sangue), mas um dois sem intervalo (dois sangues em um mesmo corpo), onde só se pode estar na relação de um dos lados, sob uma das perspectivas.

E se, como argumentei, essa relação (a mistura) não se restringe aos mestiços, não havia motivos para supormos que, no que tange aos corpos, isso seria diferente: os corpos puros são tão duplos quanto os corpos mestiços. Assim, o corpo mestiço é, poder-se-ia dizer, o modelo da relação entre esses dois pontos de vista. A procriação - o que diferencia, afinal, puros e mestiços - é apenas uma parte do processo de construçáo de um corpo-pessoa propriamente indígena (humano). Nem mesmo a concepção é, como entre nós, aquele momento mágico 
que inaugura um processo de desenvolvimento biológico autônomo. Entre os Karajá, como entre muitíssimos outros grupos ameríndios, a formação do feto depende de contínuas relações sexuais: o desenvolvimento do corpo do filho depende do acúmulo de sêmen paterno no útero ${ }^{32}$, não é algo automático. Os corpos-pessoas não nascem nem prontos, nem mesmo humanos: é necessário que se os construa, desde dentro da barriga (cf. Coelho de Souza, 2004). E, importante, isso se faz por diversos processos, que vão desde a alimentação e "técnicas corporais" (como o uso de certos adornos, escarificaçôes e aplicação de substâncias geralmente vegetais) aos cuidados e carinhos dos parentes (cf. Gow, 1997). Os "corpos aqui", em suma, "são feitos, não dados, e uma etnografia após a outra tem mostrado como os corpos são construídos e transformados por meio do compartilhamento de substâncias como os alimentos, as palavras e as doenças" (Gow, 2003, p. 66). Em Buridina, todos esses processos são misturados, tanto para os indios puros quanto para os mestiços. Já falamos, por exemplo, como se come tanto "comida de índio" quanto "comida de tori"; como a maior parte das pessoas tem tanto parentes iny quanto tori; como se tem dois nomes, um indígena e outro náo ${ }^{33}$. Para tudo, enfim, há dois lados.

A mestiçagem é a linguagem privilegiada pelos Karajá de Buridina para falar da mistura, justamente porque o corpo mestiço, contendo em si os dois sangues, sem nunca os misturar, encarna ele próprio o modelo da relaçáo entre as perspectivas: contendo ambos os pontos de vista em si, ele é a própria relação. Acredito que é através dessa linguagem corpórea que os Karajá têm pensado sobre sua experiência de intensa inter-relação com o mundo dos tori hãwa mahãdu, os brancos da cidade. Afinal, "em um mundo onde tudo o que existe na realidade é corporificado, os processos corporais são a principal linguagem para todos os [demais] processos" (Rodrigues, 2008, p. 474). A cultura é algo que se guarda no sangue.

Of Double Bodies: Mestiçagem, Mixture and Relation among the Karaja of Buridina (Aruanã - Goiás)

abstract Buridina is a small Karajá village within the center of the tourist city of Aruanã (Goiás, Central Brazil), by the Araguaia river side. In the 1970 s, its population started a series of marriages with the local non-indigenous people. Today, most of them are mestiços. This fact, added to this population's wide knowledge of and involvement with the non-indigenous world, often caused Buridina to be stigmatized as acculturated. By considering interethnic marriages, the children generated by them and the way the Karajá classify these children as a start point to explore the indigenous form of the relation between indigenous and non-indigenous perspectives, this article argues that, for the inhabitants of Buridina, learning and experiencing the world of the (non-indigenous) tori does not imply a sort of "cultural loss". Rather than a process of acculturation, it is matter of a double bodily experience in which both perspectives are related to each other in a divided unit.

keywords Mestiçagem. Mixture. Karajá indians of Buridina village. Perspective. Relationship to non-indigenous people.

\section{Notas}

1. Este texto é uma versão resumida de um dos capítulos de minha monografia de graduação (Nunes, 2009), fruto de uma pesquisa de campo de quatro meses entre os Karajá da aldeia Buridina (Aruanã - GO).

2. Inỹ é o termo de autodesignação dos Karajá, Javaé e Karajá do Norte (Xambioá); Rybè significa "fala", "língua", "modo de falar". Essa língua apresenta uma diferenciaçáo da fala segundo o sexo do falante, geralmente caracterizada pela inserção, na variante fe- 
minina, de uma consoante (majoritariamente o " $k$ ", mas também o " $\mathrm{n}$ " e o "tx"), onde há um encontro vocálico na fala masculina (ou no caso de algumas palavras iniciadas com vogais). Os parênteses nas palavras grafadas nesta língua representam a inserção da consoante na fala feminina.

3. Esse córrego, juntamente com outro, Xibiu, situado pouco mais a jusante, são, hoje, os limites respectivamente sul e norte da Gleba I da T.I. Karajá de Aruanã, que ainda conta com duas outras glebas. Para informações sobre as áreas e detalhes do processo de demarcação iniciado em 1986, cf. Braga, 2002.

4. Cf. Nunes (2009) para uma descrição mais detalhada da história da aldeia.

5. Para mais informaçóes sobre o projeto, cf. Pimentel da Silva, 2009.

6. A planta das aldeias karajá é tradicionalmente composta por uma ou mais fileiras de casas paralelas ao rio e, nos locais onde as há, uma "casa de aruanã”, hetokrè, situada na regiáo mediana da fileira das residências e delas um pouco afastada na direção do mato. Cf. Toral (1992, p. 51-56), Krause (1941, p. 253-254), Donahue (1982, p. 181; 183-184).

7. Cf. Portela (2006) e Motta (2004) sobre o imaginário da populaçáo regional e dos turistas sobre os índios de Buridina.

8. A escolha desse autor é um tanto aleatória, e muitos outros e outras poderiam substitui-lo para o fim em questão. Se optei por ele, entretanto, certamente é devido à influência que seu trabalho teve sobre o meu.

9. Tanto para os indígenas quanto para os regionais, "o falar bem o português (ao lado de se vestir e de se paramentar de utensílios 'civilizados') simboliza a passagem da condição de 'selvagem' (...) para a de 'civilizado"” (Op. cit., p. 100).

10. Advirto que este é o termo que escolhi utilizar para definir o processo em questáo. O conceito utilizado pelos Karajá é mistura, que, como veremos, tem um significado algo mais abrangente que este outro. Assim, utilizo mestiçagem para me referir estritamente aos casamentos entre índios e regionais e às crianças deles resultantes.

11. Esclareço que os trabalhos de [Cavalcanti-]Schiel (2002; 2008) já haviam registrado essa tricotomia classificatória básica e abordado alguns aspectos relativos à mestiçagem, e, assim, acabaram por se constituir com um de meus pontos de apoio.

12. Veremos mais à frente, porém, que essas duas formas de pensar a mestiçagem não se contradizem. Cf. infra, nota 24 .
13. O Diagrama 1, advirta-se, não é genealógico: ele apenas sintetiza (com o engessamento próprio desse tipo de representação), a lógica dos cálculos feitos pelos Karajá a partir de ambos os idiomas, o da geraçấo e o da distância.

14. Se os cálculos da mistura feitos pelos Karajá de Buridina e Karajá do Norte (Xambioá) são idênticos, operando, ao que tudo indica, pelos mesmos princípios de distanciamento e aproximaçáo, qual seria o sentido dessa singular diferença? O que mais interessa nessa questáo, acredito, é pensarmos o que permite que a mesma "equação" $(\mathrm{M}+\mathrm{M}=)$ gere dois resultados distintos ( $\mathrm{M}$ ou $\mathrm{P})$, i.e., qual o princípio de transformação que nos permite passar de um para outro. Um tal exercício seria análogo ao de Peter Gow, no qual ele analisa "como o fenômeno 'ex-Cocama' faz sentido enquanto uma variante transformacional de outros sistemas de parentesco amazônicos; e argumentarei que, nessa medida, ele não consiste em uma evidência do colapso da lógica social indígena, mas sim em sua continua transformação" (2003, p. 58 - grifos meus).

15. Patrícia Rodrigues diz sobre os Javaé que "não se acredita que o parentesco seja baseado no compartilhar de um mesmo sangue": reconhecem-se laços bilaterais de descendência pela "mistura do sêmen paterno [que forma o corpo da criança] e de influências menos visíveis das substâncias maternas", configurando uma consubstancialidade que não é uma consanguinidade (2008, p. 521). Quando os Karajá falam de sangue, porém, não parecem estar se referindo à substância-sangue. Quando perguntei a algumas pessoas se a criança, quando nascia, trazia consigo tanto o sangue da mãe quanto o do pai, recebi sempre uma negaçáo como resposta. Assim, quando dizem, por exemplo que "o sangue puxa", estão se referindo a uma conexão entre os pais e a criança - os "laços bilaterais de descendência” de que fala Rodrigues - cujo veículo não parece ser a substância do sangue. Eis aqui uma dimensão da etnografia Karajá e Javaé que ainda merece ser mais explorada.

16. Um desses casamentos não aparece nas tabelas a seguir por a pessoa em questão não fazer parte do grupo aqui levado em consideração (cf. nota 17).

17. As informaçóes que se seguem foram retiradas em parte dos censos referentes aos anos de 2008 e 2009, feitos pela Funasa, e complementadas com meus próprios levantamentos. Considerei aqui apenas o grupo dos originais de Buridina, pois as famílias vindas recentemente da Ilha do Bananal certamente não têm a mesma experiência histórica que os habitantes de Buridina, o que poderia gerar algumas distorçóes -

cadernos de campo, São Paulo, n. 19, p. 113-134, 2010 
I32 EduARDo S. NuneS

o aumento do número de casamentos entre dois índios puros, e.g.; quanto às poucas pessoas que moram dispersas pela cidade, parte de uma só família, tive poucas oportunidades de conviver com elas - as informaçóes que possuo a seu respeito sendo, por este motivo, fragmentárias -, o que me faz recuar e me esquivar de estender o conteúdo deste trabalho também à experiência delas.

18. Cf. Donahue (1982, p. 147-151) para uma descrição do haräbie, "o casamento arranjado tradicional". Cf. também Rodrigues (2008, p. 745-757), Dietschy (1978, p. 74-75) e Fénelon Costa (1978, p. 47).

19. "Ah, Karajá mesmo é poder viver só da caça e da pesca, poder ficar bem longe do pessoal dos brancos, poder falar só na linguagem dos índios", disse um jovem de Buridina (Portela, 2006, p. 206 - grifos originais omitidos).

20. Hâwa é um conceito geralmente traduzido pelos índios como aldeia, mas às vezes também como lugar onde se situa/constrói uma aldeia, ou simplesmente como lugar. Rodrigues diz que "hãwa é tanto uma 'aldeia’ quanto um território definido ao redor de uma aldeia” (2008, p. 247, nota 7). Se as aldeias karajá são inỹ hãwa, as cidades dos brancos são tori hãwa, "aldeia/território/lugar dos brancos". Esta informação está também presente na etnografia de Donahue (1982, p. 172).

21. A tradução aproximada do termo seria "pessoal (mahãdu) da cidade (tori hawã)".

22. Não tenho certeza sobre por que um determinado nome se fixa como o principal. Donahue (1982, p. 127) sugere que seja pela preferência dos pais. Ouvi de alguns Karajá que, simplesmente, "o primeiro nome é o que fica”. De outros, que isso pode ser uma função da relação que os pais entretêm com os nominadores. Assim, se um dos nomes foi dado por uma avó muito respeitada pelos pais da criança, haveria uma chance maior de este ser o nome a se fixar.

23. Sobre nominação, cf. Rodrigues (2008, p. 671-672), Donahue (1982, p. 127-128), Dietschy (1978, p. 75), Krause (1943, p. 201).

24. Os Karajá traduzem o termo lahi, do inỹrybè, pelo termo avó, do português. Em ambas as línguas, entretanto, mantém-se o significado do termo indígena: lahi é toda e qualquer mulher da segunda geração ascendente para cima $(\mathrm{G}+2, \mathrm{G}+3 \ldots)$. O mesmo vale para o par masculino: avô e labi(k)è.

25. Cf. Rodrigues e sua argumentação, com base numa extensa narrativa mitológica javaé, de que a 'sociedade javaé é ela própria o resultado de uma mistura, "uma relação criativa entre diferentes” onde não há termos anteriores a ela (2008, p. 103). Ou, como numa fala já citada, "Porque todos nós, seres humanos, somos assim, misturados". É nesse registro, penso, que podemos inscrever aquela afirmação, destoante do restante dos cálculos da mistura, de que "misturou, está misturado. Não volta a ser puro mais não”.

26. Aqui há um outro exemplo da lógica do movimento das fronteiras do conceito de "puros", em oposição a misturados, descrita acima. Em Coelho de Souza (2002) podemos encontrar uma descrição, a partir de uma análise dos termos de autodesignação de vários grupos jê, da maneira como o par de oposiçôes humano/não humano se replica em níveis distintos, fazendo com que pessoas que se enquadram na categoria de humanos em um nível, em outro não mais o sejam.

27. Cf. a esse respeito Rodrigues (2008, p. 697) e Dietschy (1978, p. 79).

28. O caso dos Wari', cuja descrição de Vilaça (1992; 2000; 2006) em praticamente tudo se aproxima da que faço aqui, guarda, porém, uma diferença nesse ponto. Por uma situação que os levou a morarem próximos de alguns outros grupos indígenas, inimigos, os Wari' procederam a uma incorporação destes. "Constituindo sempre uma minoria em cada posto, estes índios se casam com os Wari', comem sua comida e adotam sua língua. Se antes eram chamados wijam, inimigos, são hoje, em vários contextos, classificados como Wari', especialmente quando se quer diferenciá-los dos brancos. (...) Nos dias de hoje, os brancos são os únicos a serem insistentemente chamados de wijam" (Vilaça, 2006, p. 494-495). Os Wari' "aproximaram-se dos brancos mantendo-os diferentes, inimigos. Os demais inimigos com os quais passaram a conviver foram, como vimos, 'warinizados' pela convivência e, sobretudo, pelo casamento. Não oferecem mais uma diferença a ser experimentada. Os Wari' entendem que, em relação aos brancos, essa diferença poderia de algum modo ser preservada, e optaram por isso evitando o meio definitivo de anulá-la, o casamento" (Op. cit., p. 502). Os Karajá de Buridina, como vimos, se aproximaram dos brancos justamente por meio do casamento, e, diria eu, não se esforçam para que essa diferença seja mantida. Em muitos contextos podemos escutá-los dizendo coisas como "eu penso no lado da pessoa, não importa se é índio ou se não é”, ou, como ouvi certa vez sobre um homem karajá que havia cometido um crime, "eu sei que ele é índio, mas o que ele fez está errado, acho que ele tem que pagar", anulando, assim, a diferença entre as maneiras indígenas e policiais de resoluçáo do conflito. De algum modo, entretanto, essa dife- 
rença se mantém. Talvez, como no caso em voga dos cônjuges tori, sejam os brancos mesmo que insistam em fornecer elementos que explicitam sua dimensão Outro. Mas esta é ainda uma questão para se refletir.

29. "É a cruz indígena", artefato de madeira adornado que se coloca na cabeceira do túmulo. Cf. Ehrenreich (1948, p. 66-68).

30. Cf. o restante da descrição aqui resumida em Vilaça, 1992, p. 79-83; 2006, p. 202-207.

31. Cf. supra, nota 28. Quanto a isso, seria também necessário explorar a maneira como os Karajá pensam a proximidade física operada pelo casamento (alimentação, relaçóes sexuais e convivialidade) - tratar-se-ia de uma consubstancialização ou consanguinização? Seja como for, o casamento não parece ser um operador de transformação. Os casos de Buridina e de Txuiri, aldeia na qual os Karajá expressam "sua preferência por genros tori, porque isso permitiria que suas filhas aprendessem mais facilmente as 'coisas dos civilizados"” (Bonilla, 2000, p. 79), indicam justamente o contrário, que a proximidade do matrimônio parece ser mesmo uma forma de experimentação e conhecimento, que, como já dito, não anula a diferença entre eles e os tori.

32. Sobre o caso karajá, cf. Donahue (1982, p. 106) e Lima Filho (1994, p. 132). Sobre os Javaé, cf. Rodrigues (1993, p. 50-51).

33. Os nomes são partes constituintes e constitutivas das pessoas. Coelho de Souza fala de uma "dupla face dos nomes": eles têm uma dimensão "corpo", "pele", e outra dimensão "alma”, uma parte durável da pessoa, ambas as faces sendo importantes no processo de sua construçáo (2002, p. 573). Rodrigues fala dos nomes como uma "substância invisível" que, enquanto tal, é transmitia pela nomeação, pode ser externalizada pela utilização dos nomes próprios como vocativo (num processo análogo à externalização do sangue através de um corte na pele), etc. "Os nomes", em suma, "são componentes essenciais da formação da pessoa" (2008, p. 681ss).

\section{Referências bibliográficas}

BONILLA, Lydie Oiara. Un village sans cimetière: regard ethnographique sur l'établissement d'une communauté Javaé dans un village de colons, Porto Txuiri, Ilha do Bananal (Brésil Central). Nanterre: Mémoire de Maîtrise d'Ethnologie, Université de Paris X, 1997. BONILLA, Lydie Oiara. Reproduzindo-se no mundo dos brancos: Estruturas KARAJÁ em Porto Txuiri (Ilha do Bananal - Tocantins). Dissertação (mestrado). Museu Nacional, Universidade Federal do Rio de Janeiro, Rio de Janeiro, 2000.

BRAGA, André. G. A demarcação de Terras Indígenas como processo de reafirmaçâo étnica: o caso dos Karajá de Aruanã. Monografia (graduação). Departamento de Antropologia, Universidade de Brasília, Brasília, 2002.

CARDOSO DE OLIVEIRA, Roberto. $O$ indio e o mundo dos brancos. São Paulo: Pioneira, 1972 [1964].

[CAVALCANTI-]SCHIEL, Helena M. Etnicidade ou lógica cultural? Os Karajá de Buridina e a cidade de Aruanã. Monografia (graduação). Departamento de Antropologia, Universidade de Brasília, Brasília, 2002.

CAVALCANTI-SCHIEL, Helena M. Dançando cacofonias. A relaçáo aldeia-cidade entre os Karajá. Ensaio inédito.

COELHO DE SOUZA, Marcela. O Traço e o círculo: o conceito de parentesco entre os jê e seus antropólogos. Tese (doutorado). Museu Nacional, Universidade Federal do Rio de Janeiro, Rio de Janeiro, 2002.

COELHO DE SOUZA, Marcela. Parentes de Sangue: incesto, substância e relação no pensamento timbira. In: Mana, n. 10(1), p. 25-60, 2004.

COELHO DE SOUZA, Marcela. A pintura esquecida e o desenho roubado. Contrato, troca e criatividade entre os Kïsêdjê. Texto apresentado no seminário LINDE/PROCAD “Dos Quatro Cantos da Amazônia: Conhecimento indígena como prática de transformação”. UnB, Brasília, 21 de Setembro de 2009.

DIESTSCHY, Hans. Le système de parenté et la structure sociale des indiens Carajá. In : Actes du Vie Congrés International des Sciences Anthropologiques et Ethnologiques, Paris 1960, vol. 2/1, 1963.

DIESTSCHY, Hans. Graus de Idade entre os Karajá do Brasil Central. In: Revista de Antropologia, n. 21, p. 69-86, 1978.

DONAHUE, George. A Contribution to the Ethnography of the Karaja Indians of Central Brazil. Tese (doutorado). Universidade da Virgínia, Charlottesville, 1982.

EHRENREICH, Paul. Contribuiçóes para a etnologia do Brasil. In: Revista do Museu Paulista, vol. 2, p. 7-135, 1948.

FÉNELON COSTA, Maria Heloisa. A arte e o artista na sociedade karajá. Brasília: Funai, 1978.

GOW, Peter. Of Mixed Blood. Kinship and History in Peruvian Amazonia. Oxford: Clarendon Press, 1991.

GOW, Peter. O parentesco como consciência humana: o caso dos Piro. In: Mana, n. 3(2), p. 39-65, 1997.

GOW, Peter. "Ex-cocama": identidades em transformação na Amazônia Peruana. In: Mana, n. 9(1), p. 57-79, 2003.

cadernos de campo, São Paulo, n. 19, p. 113-134, 2010 
I 34 EduARdo S. NuneS

KRAUSE, Fritz. Nos Sertōes do Brasil. In: Revista do Arquivo Municipal de São Paulo, vol. 78, p. 233-256, 1941.

KRAUSE, Fritz. Nos Sertōes do Brasil. In: Revista do Arquivo Municipal de São Paulo, vol. 88, p. 183-205, 1943.

LEITE, Luciano Mendes. Uma aldeia na cidade - O contato interétnico entre os Karajá de Aruanã e a sociedade nacional. Monografia (graduação). Departamento de Antropologia, Universidade de Brasília, Brasília, 2007.

LIPKIND, William. The Carajá. In: STEWARD, J. (Org.). Handbook of South American Indians, vol. 3. Washington, 1948. pp. 179-191.

MOTTA, Olga Maria Fernandes. Os Karajá, o Rio Araguaia e os Outros: territorialidades em conflito. Dissertação (mestrado). Programa de Pós-Graduação em Geografia, Universidade Federal de Goiás, 2004.

NUNES, Eduardo S. A cruz e o itxe (k)ò: mestiçagem, mistura e relação entre os Karajá de Buridina (Aruanã - GO). Monografia (graduação). Departamento de Antropologia, Universidade de Brasília, Brasília, 2009.

PÉTESCH, Nathalie. A trilogia karajá: sua posiçâo intermediária no continuum jê-tupi. In: VIVEIROS DE CASTRO, E.; CARNEIRO DA CUNHA, M. (Orgs.). Amazônia: etnologia e história indígena. São Paulo: NHII-USP/Fapesp, 1993. p. 365-382.

PIMENTEL DA SILVA, Maria do Socorro. Reflexōes sociolinguísticas sobre línguas indígenas ameaçadas. Goiânia: Editora da UCG, 2009.

PORTELA, Cristiane de Assis. Nem ressurgidos, nem emergentes: a resistência histórica dos Karajá de Buridina em Aruanã - GO (1980-2006). Dissertação (mestrado). Departamento de História, Universidade Federal de Goiás, Goiânia, 2006.

RODRIGUES, Patrícia de Mendonça. O povo do meio: tempo, cosmo e gênero entre os Javaé da Ilha do Ba- nanal. Dissertação (mestrado). Departamento de Antropologia, Universidade de Brasília, Brasília, 1993.

RODRIGUES, Patrícia de Mendonça. A caminhada de Tanỹxiwè: uma teoria Javaé da história. Tese (doutorado). Departamento de Antropologia, Universidade de Chicago, Chicago, 2008.

SEEGER, Anthony. A identidade étnica como processo: os índios suyá e as sociedades do Alto Xingu. In: Anuário Antropológico 78. Rio de Janeiro: Tempo Brasileiro, 1980.

TORAL, André Amaral de. Cosmologia e Sociedade Karajá. Dissertação (mestrado). Museu Nacional, Universidade Federal do Rio de Janeiro, Rio de Janeiro, 1992.

VASCONCELOS, José Mauro de. Arara Vermelha. São Paulo: Ediçôes Melhoramentos, 1965.

VILAÇA, Aparecida. Comendo como gente. Formas de canibalismo Wari'. Rio de Janeiro: Editora da UFRJ/ Anpocs, 1992.

VILAÇA, Aparecida. O que significa tornar-se outro? Xamanismo e contato interétnico na Amazônia. Revista Brasileira de Ciências Sociais, vol. 15, n. 4, p. 56-72, 2000.

VILAÇA, Aparecida. Chronically Unstable Bodies: Reflections on Amazonian Corporalities. In: The Journal of the Royal Anthropological Institute, vol. 11, n. 3, p. 445-464, 2005.

VILAÇA, Aparecida. Quem somos nós? Os Wari' encontram os brancos. Rio de Janeiro: Editora da UFRJ, 2006.

VIVEIROS DE CASTRO, Eduardo. O mármore e a murta: sobre a inconstância da alma selvagem. In: $A$ inconstância da alma selvagem. São Paulo: Cosac Naify, 2002a. p. 181-264

VIVEIROS DE CASTRO, Eduardo. Perspectivismo e multinaturalismo na América indígena. In: $A$ inconstância da alma selvagem. São Paulo: Cosac Naify, 2002b. p. 345-399.

autor

Eduardo S. Nunes

Mestrando em Antropologia Social / UNB

Recebido em 07/03/2010

Aceito para publicação em 20/09/2010

cadernos de campo, São Paulo, n. 19, p. 113-134, 2010 